\title{
More, Huxley, Eggers, and the Utopian/Dystopian Tradition
}

\author{
PETER C. HERMAN
}

San Diego State University

\begin{abstract}
From its inception in Plato's Republic and revival in Thomas More's Utopia, the concept of a perfect (or as More originally put it in a qualification often lost, "best") form of a republic has been dogged by the spectres of hypocrisy, contradiction, and authoritarianism. However, the matter is more complicated than a simple declaration that utopias provide a vehicle for totalitarian fantasy, that totalitarian governments inevitably portray themselves as creating a utopia. While today's readers, at a comfortable distance from the early sixteenth century, may bridle at the lack of privacy, or at the ideological coerciveness in More's Utopia, that does not eradicate how, in Walter Kendrick's words, "what for us are problems are for them solutions." It can be argued that the negative elements are a response to social ills. The same goes for Aldous Huxley's Brave New World and Dave Eggers's The Circle. While the negatives in all three fictions undermine or put into question the positives, our realization that the authors also intended the negatives as genuine attempts at resolving genuine problems that cause untold misery invites us to complicate our judgments. The undermining is itself undermined.
\end{abstract}

L'idée d'un gouvernement parfait (ou "meilleur " pour reprendre l'expression même de More), de son apparition dans la République de Platon jusqu’à son renouveau dans l'Utopie de Thomas More, a été traquée et mise à profit par les partisans de l'hypocrisie, de la contradiction et de lautoritarisme. Toutefois, la question est plus complexe que la simple affirmation qui voudrait que les utopies favorisent les phantasmes totalitaires, ou que les gouvernements totalitaires se présentent inévitablement comme la réalisation d’une utopie. Ces éléments négatifs répondent en fait souvent à de véritables problèmes sociaux, et, bien que le lecteur d'aujourd'hui, dans la confortable distance qui le sépare du début du XVIe siècle, puisse s’indigner du manque de vie privée et de l'intransigeance idéologique de l'Utopie de More, cela ne change pas le fait que, pour emprunter la formule de Walter Kendrick, "ce qui pour nous sont des problèmes, sont pour eux des solutions». Il en va de même pour le Brave New World de Aldous Huxley et The Circle de Daver Egger. Alors que les aspects négatifs dans ces trois fictions compromettent leurs aspects positifs, le fait de reconnaitre que ces auteurs, par ces moyens discutables, ont sincèrement tenté de régler de vrais problèmes entraînant des misères infinies, amène le lecteur d'aujourd'hui à nuancer ses jugements. Et ainsi, les aspects compromettants de ces œuvres sont eux-mêmes remis en question.

\section{Toward the beginning of Dave Eggers's 2013 novel, The Circle, the book's central character, Mae, exclaims that she has landed a job in heaven: ${ }^{1}$}

1. Dave Eggers, The Circle (New York: Knopf/McSweeney's Books, 2013). All further references will be parenthetical. 
Outside the walls of the Circle, all was noise and struggle, failure and filth. But here, all had been perfected. The best people had made the best systems and the best systems had reaped funds, unlimited funds, that made possible this, the best place to work. And it was natural that it was so, Mae thought. Who else but utopians could make utopia? (30)

In this passage, Eggers draws on the common perception of utopia as "[a]n imagined or hypothetical place, system, or state of existence in which everything is perfect," ${ }^{2}$ and one can certainly see why Mae would feel this way. The Circle appears to be a perfect place to work: humane working conditions, incredibly smart colleagues, extremely generous benefits covering both the employee and his or her family, all geared toward creating socially useful products aimed at achieving social justice and eradicating tyranny. Still, as numerous reviewers pointed out, this utopia is nowhere near as utopian as Mae thinks. ${ }^{3}$ In fact, Eggers's fictional tech company resembles the Party in 1984 in its drive for power and crushing of dissent. ${ }^{4}$ In a word, the Circle is a dystopia.

Eggers's treatment of utopia seems to draw on the equally common perception of imagined perfect societies as inherently tyrannical. From its inception in Plato's Republic and revival in Thomas More's Utopia, ${ }^{5}$ the concept of a perfect (or as More originally put it in a qualification often lost, "best") form of a republic has been dogged by the spectres of hypocrisy, contradiction, and authoritarianism. "There is tyranny in the womb of every utopia," declares the economist Bertrand de Jouvenel, and one can find similarly skeptical comments from writers as disparate as G. K. Chesterton, Karl Popper, and

\section{Oxford English Dictionary (OED), s.v. “utopia," accessed 1 June 2018, http://www.oed.com/.}

3. See, for example, Ellen Ullman, "Ring of Power," New York Times, 1 November 2013, http://www. nytimes.com/2013/11/03/books/review/the-circle-by-dave-eggers.html, and Edward Docx, "The Circle by Dave Eggers-Review," The Guardian, 9 October 2013, https://www.theguardian.com/books/2013/ oct/09/circle-dave-eggers-review.

4. Stephen Beck, “Is Dave Eggers' ‘The Circle' Our Generation's '1984'?” The Daily Beast, 2 October 2013, http://www.thedailybeast.com/articles/2013/10/02/is-dave-eggers-the-circle-our-generation-s-1984. html.

5. J. C. Davis notes that "for a thousand years, perhaps longer, no European had conceived of a utopia and committed it to paper," in Utopia and the Ideal Society: A Study of English Utopian Writing 1516-1700 (Cambridge: Cambridge University Press, 1981), 42.

6. Akash Kapur, “Couldn’t Be Better: The Return of the Utopians," The New Yorker (3 October 2016): 66. 
Christopher Hitchens. ${ }^{7}$ However, the matter is more complicated than a simple declaration that utopias provide a vehicle for totalitarian fantasy, that totalitarian governments inevitably portray themselves as creating a utopia, or, as Krishan Kumar has it, that utopia and dystopia are opposites "locked together in a contrapuntal embrace." ${ }^{8}$ The negative elements often respond to genuine social ills, and while today's readers, at a comfortable distance from the early sixteenth century, may bridle at the lack of privacy, or at the ideological coerciveness in More's Utopia, it can still be argued that, in Walter Kendrick's words, "what for us are problems are for them solutions." The same goes for Brave New World and The Circle. While the negatives in all three fictions undermine or put into question the positives, realizing that the authors also intended the negatives as genuine attempts at resolving genuine problems that cause untold misery invites contemporary readers to complicate our judgments. The undermining is itself undermined.

For Thomas More, everything in Utopia responds to the enclosure movement and the tyranny of Richard III. Similarly, Aldous Huxley's tale of a World State, drug-induced happiness, mass consumption, and fetal engineering responds to World War I and the dehumanization of labour inherent in Henry Ford's assembly lines. For Dave Eggers, the Circle's embrace of tech utopianism aims to resolve a host of social ills, from the inconveniences of multiple passwords and Internet trolls who toxify message and comment boards to child abduction, human rights abuses, and political oppression. Even more broadly, the Circle proposes that social media can allow everyone to believe that their life means something, that their existence makes an important difference in the world.

7. Bertrand de Jouvenel, Sovereignty: An Inquiry into the Political Good (Chicago: University of Chicago Press, 1957), 10; G. K. Chesterton, Heretics (New York and London: John Lane, 1905), 79; Karl Popper, The Open Society and Its Enemies: The Spell of Plato (London: Routledge \& Kegan Paul, 1952), 1:159-60; and Christopher Hitchens, "Foreword," in Aldous Huxley, Brave New World and Brave New World Revisited (New York: HarperCollins, 2004), xxi.

8. Krishan Kumar, Utopia and Anti-Utopia in Modern Times (Oxford: Blackwell, 1989), 99.

9. Walter Kendrick, Utopia, Carnival, and Commonwealth in Renaissance England (Toronto: University of Toronto Press, 2004), 35. While Hannah Arendt does not address the connections between utopianism and fascism directly in The Origins of Totalitarianism (New York: Harcourt Brace, 1966), the sense of selflessness in totalitarian societies, the belief that only the collective matters, not the individual, has obvious implications for Brave New World and 1984 (Arendt, 315). 
My larger point, however, in bringing More's Utopia (1516) into conversation with Brave New World (1932) and The Circle (2013) is to demonstrate how More's fiction constitutes the fons et origo of the later books, not only in terms of projecting a version of a perfect society, but in incorporating the critique of that society into the narrative. The later books, in other words, show how More's Utopia remains a vital shaping presence five hundred years after it appeared.

1.

Let me begin with a truism: Thomas More departed from his model, Plato's Republic, by producing in Utopia a work that regularly undermines itself. ${ }^{10}$ The book consists of a dialogue between Morus (a "fool") and Hythlodaeus ("well-learned in nonsense" [48; 301n]) about a place that is both "no-place" (u-topia) or "Nusquam," to use More's Latin translation of his title, and "happy place" (eu-topia). ${ }^{11}$ The island has a river called "waterless ("An-ydrus" [116; 392n.]), and the Utopians are ruled wisely by a group of silly old men and plain gluttons ("syphogrants" and "tranibors" [122; 398n]). Assertions are made, then unmade. Utopians may travel as they please, "unless some good reason prevents them" (145). They hate war "as an activity fit only for beasts" (199), but then there are so many exceptions that one wonders if Utopians exist in a constant state of battle. ${ }^{12}$ The Utopians have the freedom to believe as they will

10. Stephen Greenblatt, for example, notes that throughout the book, "freedoms are heralded, only to shrink in the course of the description," in Renaissance Self-Fashioning (Chicago: Chicago University Press, 1980), 41. Robert Appelbaum, summarizing the view of most readers today, writes that "the meaning of Utopia [...] is inherently indefinite and unstable," in "Utopia and Utopianism," in The Oxford Handbook of English Prose 1500-1640, ed. Andrew Hadfield (Oxford: Oxford University Press, 2013), 258. Even so, a number of scholars continue to read Utopia as a straightforward criticism of European and English social practices. See, for example, Dominic Baker-Smith, "The Escape from the Cave: Thomas More and the Vision of Utopia," in Between Dream and Nature: Essays on Utopia and Dystopia, ed. Dominic Baker-Smith and C. C. Barfoot (Amsterdam: Rodopi, 1987), 5-19.

11. Thomas More, Utopia, ed. Edward Surtz and J. H. Hexter, in The Complete Works of St. Thomas More (New Haven: Yale University Press, 1965). All further references will be to this text and cited parenthetically. Alistair Fox, Thomas More: History and Providence (New Haven: Yale University Press, 1982), 56.

12. On the contrast between Utopian pacifist rhetoric and their bellicosity, see Schlomo Avineri, "War and Slavery in More's Utopia," International Review of Social History 7 (1962): 260-90; George Logan, 
ever since King Utopus "made the whole matter of religion an open question" (134), but the very next sentence imposes restrictions: "By way of exception, he conscientiously and strictly gave injunction that no one should fall so far below the dignity of human nature as to believe that souls likewise perish with the body or that the world is the mere sport of chance and not governed by divine providence" (134). More even ends Utopia by explicitly inviting the reader to view his island skeptically: "Many things seemed very absurdly established in the customs and laws of the people described" (151), such as "their method of waging war," religion, and doing away with private property and money, which "alone utterly overthrows all the nobility, magnificence, splendor, and majesty" of life (245). All of this is well known.

But perhaps less frequently recognized is how many of Utopia's most negative attributes arise as solutions to intractable social and political problems, which should then encourage us to revisit our judgments. The worst consequences, it seems, result from the best intentions, and we are always left asking if, given the magnitude of the problem addressed, the consequences are really as bad as we tend to think. Let me give three examples.

Today's readers have repeatedly noted how "More's ideal commonwealth turns out to be a repressive, even totalitarian state." ${ }^{13}$ Because there is no private property in Utopia, "every ten years they actually exchange their homes by lot" (121). As for clothing, "these are of one and the same pattern through the island and down the centuries, though there is a distinction between the sexes and between the single and married" (127). No one is forbidden to cook for oneself and eat at home, "yet no one does it willingly since the practice is considered not decent and since it is foolish to take the trouble of preparing an inferior dinner when an excellent and sumptuous one is ready at hand in the hall nearby" (141). The only mode of personal expression allowed, it seems, is gardening (121).

The Meaning of More's "Utopia" (Princeton: Princeton University Press, 1983), 221-29.

13. Stephanie Elsky, "Common Law and the Commonplace in Thomas More's Utopia," English Literary Renaissance 43.2 (2013): 199. More's editor, J. H. Hexter, observed that "the way of life of the Chinese as prescribed by Chairman Mao [...] sounds uncomfortably like Utopia in a number of significant respects," in The Vision of Politics on the Eve of the Reformation: More, Machiavelli, and Seyssel (New York: Basic Books, 1973), 125n8. More recently, James Simpson argues that Utopia "promoted the most draconian repression of discursive liberty," in The Oxford History of English Literary History, 1350-1547: Reform and Cultural Revolution (Oxford: Oxford University Press, 2002), 231. 
Oppressive as they may sound to contemporary and Henrician readers (England's middle and upper classes not being known for their asceticism), these strict measures respond to the enclosure movement and the misery it produced. Famously, in book 1, Hythlodaeus traces the epidemic of thieving to enclosures:

Your sheep $[\ldots]$ which are usually so tame and so cheaply fed, begin now, according to report, to be so greedy and wild that they devour human beings themselves and devastate and depopulate fields, houses and towns. [...] Consequently, in order that one insatiable glutton [...] may join field to field and surround many thousand acres with one fence, tenants are evicted. Some of them $[\ldots]$ are stripped even of their own property, or else, wearied by unjust acts, are driven to sell. By hook or by crook the poor wretches are compelled to leave their homes. [...] After they have spent that trifle [the little money they receive for selling what little property they had] in wandering from place to place, what remains for them but to steal and be hanged [...] or to wander and beg? (65-67)

Nothing in Hythlodaeus's diatribe would have surprised any original reader familiar with recent English history. Between 1488 and 1515, a steady stream of proclamations and statutes denounced enclosures and tried to impose limits. ${ }^{14}$ In February 1515, for example, Parliament enacted a bill mandating that all enclosed lands be restored for agriculture (as opposed to sheep) "after the manner and usage of the county where the said land lieth."15 The bill was ignored. So, Parliament re-passed the law in 1516 and in theory made it perpetual. In reality, the laws and proclamations did little to stop the process, and enclosers showed "little humanity" to those displaced by agricultural and economic change, leaving them to survive however they may. ${ }^{16}$

Stephen Greenblatt writes that the point of Utopian housing and clothing policies (I would add dining as well) is to "eliminate the possibility of a Henry

14. John Freeman, “Raphael's 'Backward Reform': 'Agent Provocateur' or Agent Proclamateur?" ELH 70.2 (2003): 430.

15. R. W. Heinze, Proclamations of the Tudor Kings (Cambridge: Cambridge University Press, 1976), 95; Freeman, 430.

16. Isaac S. Leadam, "Introduction,” The Domesday of Inclosures, 1517-1518 (London: Royal Historical Society, 1897), 43. 
VIII," but More focuses not only on the great, but also on those made bereft and wretched by enclosures. ${ }^{17}$ If one has been evicted from one's farm, with no shelter and no means of earning a livelihood, a house "of handsome appearance with three stories" (121) and a garden probably sounds very enticing, even if you have to move every ten years. More also alleviates the lot of the few lucky, or unlucky, enough to not be thrown off their land, since no one works from dawn to dusk, "wearied like a beast of burden with constant toil from early morning till late at night" (127). Doubtless, life in Utopia seems to contemporary readers highly regimented with little to no space for personal expression, but (then as today) how oppressive one finds More's island will likely depend on one's social position. The privileged few, e.g., England's wealthy merchant and lawyer class, will likely be repulsed; of the unfortunate many, e.g., the victims of the Enclosure Movement, I'm not so sure. Similarly, More's complaint at the book's end about the Utopian refusal of a money-based economy only makes sense if you are lucky enough (as More was) to have money. Morus may say that an exchange economy grants "all the nobility, magnificence, splendor, and majesty" that constitute, "in the estimation of the common people, the true glories and ornaments of the commonwealth" (245), but if you are among the "common people" thrown off your land and forced to beg and steal to survive, you might look at Utopia's "common life and subsistence" very differently than Morus does, which I think is More's intention.

The enclosure movement also lies behind More's treatment of slavery. Few issues today are as incendiary and repellent as slavery, and critics usually either ignore or explain away the centrality of this practice to More's island. ${ }^{18}$ While it is certainly true that the classical tradition accepted slavery, crucially, More's society and legal traditions increasingly looked at slavery with revulsion. ${ }^{19}$ Remnants of villainage, or bondmen, remained officially on the books in the early sixteenth century, but at least one important legal scholar, Sir Anthony Fitzherbert, in 1523, regarded slavery as a barbaric, unchristian practice:

how be it in some places the bonde men contynue yet / the whiche me semeth is the grettest inconvenye[n]t that nowe is suffred by the lawe.

\section{Greenblatt, 39.}

18. Avineri, 260; Logan, Meaning of More's “Utopia," 226.

19. Logan, Meaning of More’s “Utopia," 176-77. 
That is to have any christen man bonden to another / and to have the rule of his body / landes \& goodes / that his wife chyldren and servauntes / have laboured for all their lyfe tyme / to be so taken / lyke as and it were extorcion or bribery. [...] for as me semeth / there shulde no man be bonde but to god / and to his king \& prince over hym. ${ }^{20}$

The 1547 Vagrancy Act tried to impose slavery as a punishment for vagrancy, but two years later, Parliament repealed the act because "thextremitie of some [of the laws] have byn occasion that they have not ben putt in use." ${ }^{21}$ While C. S. L. Davies exaggerates somewhat when he writes, "Slavery, of fellow citizens at least, was a foreign concept in the sixteenth century," there's little doubt that the slavery was increasingly viewed in the sixteenth century as antithetical to English identity. ${ }^{22}$ The Elizabethan Sir Thomas Smith, in his description of England's political organization, De Republica Anglorum (written 1562-65; published 1584), made a point of stressing how England had no slaves. After describing Justinian's distinction between slaves who were purchased and slaves who belonged to a particular place, Smith declared, "Neither of the one sort nor of the other have we any number in England." ${ }^{23}$ Smith's book circulated widely in manuscript and would be adapted by William Harrison for his description of

20. Sir Anthony Fitzherbert, Here begynneth a ryght frutefull mater: and hath to name the boke of surveyeng and improvme[n]tes (1523), cap. xiii, http://quod.lib.umich.edu/e/eebo/A00895.0001.001/1:18?ALLSEL $\mathrm{ECTED}=1 ; \mathrm{c}=$ eebo; $=$ =ebo2; $\mathrm{cite} 1=$ fitzherbert;cite1 restrict=author;g=eebogroup;rgn=div1;singlegenre $=$ All;sort $=$ occur;subview $=$ detail;type $=$ simple;view $=$ fulltext; $\mathrm{xc}=1 ; \mathrm{q} 1=$ bounden. $\mathrm{I}$ have silently changed "u" to "v" in this and other early modern texts. See I. S. Leadam, "The Last Days of Bondage in England," Law Quarterly Review 9.4 (1893): 348-65 (the Fitzherbert reference is 356), and C. S. L. Davies, "Slavery and the Protector Somerset: The Vagrancy Act of 1547," The Economic History Review, n.s. 19.3 (1966): 533-49.

21. Quoted in Davies, 533.

22. It's worth noting that in the 1523 translation of Froissart's chronicles, one of the leaders of the Peasants' Revolt promised that "they wolde do so moche to the kynge / that there shulde nat be one bondman in all Englande" (http://quod.lib.umich.edu/e/ eebo?ALLSELECTED=1;c=eebo;c=eebo2;didno=A71318.0001.001;g=eebogroup;rgn=full+text;singl egenre $=$ All;size $=25$; sort $=$ datea;start $=1$; subview $=$ detail;type $=$ simple;view $=$ reslist;xc $=1 ; q 1=$ bondman). In 1549, the Ketts revels made the same demand: "that all bondemen may be made ffre" (quoted in Leadam, “The Last Days of Bondage”, 351).

23. Thomas Smith, De Republica Anglorum (London, 1584), sig. P3v. I have silently changed "u" to "v" for Smith and Harrison. 
England prefacing Holinshed's Chronicles (1577/1587). Harrison proudly adds that if a slave manages to arrive on English soil, that person is automatically freed:

As for slaves and bondmen we have none, naie such is the privilege of our countrie by the especiall grace of God, and bountie of our princes, that if anie come hither from other realms, so soone as they set foot on land they become so frée of condition as their masters, whereby all note of servile bondage is utterlie remooved from them. ${ }^{24}$

And so, More turns a practice that English culture found abhorrent into a central facet of Utopian social organization.

But as with other Utopian customs, how one judges Utopian slavery depends on one's social position. In book 1, Hythlodaeus recounts how the Polylerites use slavery to turn the punishment for theft into something productive; rather than execute the thief (as happens in England), the Polylerites condemn the miscreants to a lifetime of hard labour; the victim gets restitution, and the thieves "are set to public works" (77). Consequently, nobody dies, and the thieves contribute to the greater good as penance: "The object of public anger is to destroy the vices but to save the persons and so to treat them that they necessarily become good and that, for the rest of their lives, they repair all the damage done before" (79).

Similarly, the Utopians turn to slavery as an alternative to worse options. They have three classes of slaves: prisoners of war (assuming the wars are fought by the Utopians themselves); people "condemned to death elsewhere for some offense" (185); and those who voluntarily enter slavery. Significantly, the latter two categories both respond to Hythlodaeus's description of the deleterious effects of the Enclosure Movement. Utopian slavery offers those condemned elsewhere to death "for some offense" a more palatable alternative than hanging. While they suffer loss of liberty, at least they remain alive, and it is surely significant that this category constitutes the majority of Utopian

24. On the circulation of Smith's manuscript, see Ian W. Archer, "Smith, Sir Thomas (1513-1577)," Oxford Dictionary of National Biography, ed. H. C. G. Matthew and Brian Harrison (Oxford: Oxford University Press, 2004); online, ed. David Cannadine (January 2008), accessed 3 November 2016, http:// www.oxforddnb.com/view/article/25906; William Harrison, Holinshed's Chronicles, The Holinshed Project (1587), 1:156. 
slaves. Granted, Hythlodaeus's description of how the Utopians come to own these people certainly appears like they go fishing for free labour ("They carry away many of them; sometimes they buy them cheaply; but often they ask for them and get them for nothing" [185]); but one can also see these actions as compassionately saving lives that would otherwise be lost for crimes that (remembering Hythlodaeus's views on hanging people for theft) should not merit death. Similarly, the third category seems to be aimed at those dispossessed by enclosures: "sometimes a hard-working and poverty-stricken drudge of another country voluntarily chooses slavery in Utopia” (185). In book 1, Hythlodaeus declares that "it would have been much better to provide some means of getting and living, that no one should be under this terrible necessity first of stealing and then of dying for it" (61). More creates an option for such people in book 2: voluntary slavery, whereby "These individuals are well treated, and except that they have a little more work assigned to them as being used to it, are dealt with almost as leniently as citizens" (185).

On the one hand, both contemporary and early modern readers, especially in England, would likely have viewed slavery as an alternative to starvation or execution as a cure worse than the disease; therefore, slavery should be included among the "other institutions" (245) More alludes to at the book's end that serve to discredit the Utopians (like how they wage war). On the other hand, as with the blandness and regimentation of Utopian life, what seems horrific to today's readers and, given slavery's place in early modern English political thought, to More's original readers as well, may appear considerably more palatable to the dispossessed and those condemned to die for stealing so that they may live. Slavery may be antithetical to English identity, and that death might very well be preferable to a lifetime of hard labour as chattel; yet, we are not condemned to death for theft or utterly dispossessed. And so the dialectic goes, without end.

Next, let us turn to surveillance. On the one hand, Utopians are forbidden even a shred of privacy. Everyone is constantly and unremittingly "under the eyes of all" (147). Even if, by some freak accident, a Utopian finds him or herself alone, it doesn't matter, because "they believe that the dead move about among the living and are witnesses of their words and actions" (225). This is the panopticon on steroids. Yet this nonstop surveillance does not arise 
from "humanism's dark side" or a tyrant's desire to eliminate political dissent. ${ }^{25}$ Instead, the purpose of surveillance is to rid the island of crime and corruption. "The belief," writes More, "in the personal presence of their forefathers keeps men from any secret dishonorable deed" (225). "Being under the eyes of all" (the root cause for all the restrictions on travel) means "no opportunity for corruption, no lurking hole, no secret meeting place" (147). Even more specifically, More intends the nonstop observation by both the living and the dead to render impossible the political world he describes in his unfinished History of King Richard III, written at about the same time as Utopia, and very much about the political uses of interpretive murk. ${ }^{26}$

For example, More records that even as the Lord Protector seems to be planning the young Edward V's coronation, Richard secretly meets with allies to concoct an entirely different set of plans: "After they had set the lord cardinal [and other magnates], with many other noble men to commune and devise about the coronation in one place, as fast were they in another place contriving the contrary" (44). Yet even though this "very few $[\ldots]$ very secret" (44) group try to keep their plot a secret, somehow word gets out, causing "some manner of muttering among the people, as though all should not long be well" (44). ${ }^{27}$ And not only the common people, "but wise men also and some lords" began "to mark the matter and muse thereon" (45). Lord Stanley puts the matter succinctly: "'For while we, quod he, 'talk of one matter in the one place, little wot we whereof they talk in the other place" (45).

More's Utopia asks the reader to choose between living under the sort of nonstop surveillance More posits for his imaginary island-a world in which both the living and the dead observe and note every movement, every word, every breath you take-and the political universe of Richard III. While

25. Albert H. Tricomi, Reading Tudor-Stuart Texts through Cultural Historicism (Gainesville: University of Florida Press, 1996), 31.

26. George Logan, "More on Tyranny: The History of King Richard the Third" in The Cambridge Companion to Thomas More, ed. George Logan (Cambridge: Cambridge University Press, 2011), 168. Thomas More, "The History of King Richard III" and Selections from the English and Latin Poems, ed. Richard S. Sylvester (New Haven: Yale University Press, 1976). All further references will be to this text and cited parenthetically.

27. On More's use of popular resistance in his History of Richard III, see my "Henrician Historiography and the Voice of the People: The Cases of More and Hall," Texas Studies in Literature and Language 39.3 (1997), 262-70. 
today's readers might find horrific More's vision of overwhelming surveillance, evidence once more of how utopias have a tendency toward totalitarianism, one has to wonder which world the young Edward V and his brother would have preferred. At least in More's Utopia, they would not have ended up buried "at the stair foot, meetly deep in the ground, under a great heap of stones" (88).

The island thus paradoxically combines the positive and the negative: the negative elements (lack of freedom, wraparound surveillance, slavery) resulting from positive intentions (to relieve poverty, offer a more humane alternative to execution, and remove the possibility of tyranny). How one looks at the solutions inevitably changes with one's perspective and position. Those starving due to the enclosure movement would probably overlook lack of fashion if they can be fed, clothed, and housed; those victimized by power-hungry dukes will probably think nonstop surveillance a small price to pay for political integrity. At the same time, it is hard not to be highly skeptical of Utopian social customs, especially since More explicitly distances himself from them. Thus utopia (in its contemporary definition) and dystopia continually alternate.

2.

The works that followed in Utopia's wake may have taken More's title as a name for the genre, but they generally revert back to Plato's model of portraying an ideal society without irony or undermining. ${ }^{28}$ By 1533 , according to the OED, the term "utopia" comes to mean "An imaginary island [...] presented by the narrator as having a perfect social, legal, and political system" (my emphasis) and subsequent examples of the genre follow this definition. Sir Francis Bacon's The New Atlantis (1627), Sir John Harrington's The Commonwealth of Oceana (1656), and Margaret Cavendish's Blazing World (1666) do not overtly invite skepticism over their ideal societies as More does by, for example, stating in the book's title that his island represents the "optimo," not "summus" commonwealth (cxcv). "Very good," in other words, but not the highest or,

28. For informative surveys of utopian writing in these centuries, see Nicole Pohl, "Utopianism after More: The Renaissance and the Enlightenment," in The Cambridge Companion to Utopian Literature, ed. Gerald Claeys (Cambridge: Cambridge University Press, 2010), 51-78, and Kenneth M. Roemer, "Paradise Transformed: Varieties of Nineteenth-Century Utopias," also in Claeys, ed., Cambridge Companion, 79-106. 
as Ralph Robinson translated the term for his 1556 translation, "best." 29 The same applies to eighteenth- and nineteenth-century utopias, such as Frances Brooke's The History of Emily Montague (1769), and Edward Bellamy's Looking Backwards (1888), as well as H. G. Wells's scientific utopia, Men Like Gods (1923), which gave Huxley the initial spark for Brave New World.

Similarly, the kind of complex and unstable mélange of positive and negative attributes we find in Utopia is equally absent from the counter-genre of anti-utopian or dystopian literature. These works are about "total disbelief" in utopian possibilities, ${ }^{30}$ and so there is nothing redeeming about the societies depicted in such fictions as George Orwell's 1984, Yevgeny Zamyatin's We (1921), or (to choose but one example from the very popular genre of Young Adult dystopian novels), M. T. Anderson's Feed (2002). In 1984, O'Brien is brutally upfront about the Party's goal: “The Party seeks power entirely for its own sake. We are not interested in the good of others; we are interested solely in power." ${ }^{31}$ Equally, in Feed, the corporations that rule the world (which is an environmental catastrophe due to unchecked pollution) have so little interest in anything but profit that they allow the central character to die because "we don't feel that you would be a reliable investment at this time." ${ }^{32}$

Huxley, it seems, thought that he was writing a book very much in this dystopian vein, telling his father in a letter dated 24 August 1931 that he has finished a "novel about the Future, showing the appallingness (at any rate, by our standards) of Utopia." ${ }^{33}$ Huxley intends, he continues, to "show the [adumbrating effects] on thought and feeling of such quite possible biological inventions as the production of children in bottles [... and] the prolongation of youth," the invention of soma, a "harmless but effective substitute for alcohol, cocaine, opium," etc. ${ }^{34}$ And starting with contemporary reviews, the vast majority of Brave New World's readers have taken Huxley at his word, assuming that we should regard the World State as a Taylorist nightmare in which "the principle

29. Thomas More, A frutefull pleasant, \& wittie worke, of the best state of a publique weale [Utopia], trans. Ralph Robinson (London, 1556), title page.

30. Fátima Vieira, “The Concept of Utopia”, in Claeys, Cambridge Companion, 16.

31. George Orwell, 1984 (Rpt. New York: Signet Classics, 1977), 263.

32. M. T. Anderson, Feed (Cambridge, MA: Candlewick Press, 2002), 247 (emphasis in the original).

33. Aldous Huxley, Letters of Aldous Huxley, ed. Grover Smith (New York: Harper \& Row, 1969), 351.

34. Huxley, Letters, 351. 
of mass production [is] at last applied to biology" (7), a world of nonstop sex, drugs, and mindless consumption. ${ }^{35}$ (Only rock'n'roll is missing.) The novel has become so identified with dystopia that that OED uses Brave New World as an example to define the term.

However, it would be a serious mistake to assume that Huxley intended the world of Brave New World as pure satire. In the period leading up the publication of Brave New World and just after, Huxley wrote a series of journalistic essays on England's economic conditions, and in "Science and Civilization" (originally a 1932 BBC broadcast), he seriously proposed applying "scientific facts [...] to the solution of political problems," predicting that

one of these days some apparently beneficent and humanitarian government will create a comprehensive system of State crèches and baby-farms; andwith a little systematic conditioning of infant reflexes-it will have the fate of its future subjects in its hands. From the baby-farm the already thoroughlyconditioned infant will pass to the State school. He will grow up reading State Newspapers, listening to State wireless, looking at State cinemas and theatres. By the time he reaches what is somewhat ironically called the age of reason, he will be wholly unable to think for himself. ${ }^{36}$

35. Aldous Huxley, Brave New World and Brave New World Revisited (New York: Harper, 2004). All further references will be given parenthetically. See the selection of contemporary reviews given in Aldous Huxley: The Critical Heritage, ed. Donald Watt (London: Routledge, 1997), 197-221. To give a few examples of more recent literary criticism, see E. J. Brown, Brave New World, 1984, and We: An Essay on Anti-Utopia (Ann Arbor: Ardis, 1976), 42-43; Peter Firchow, The End of Utopia: A Study of Aldous Huxley's "Brave New World" (Lewisburg: Bucknell University Press, 1984), 9; Robert S. Baker, Brave New World: History, Science, and Dystopia (Boston: Twayne, 1990), 9-10; Peter Congdon, "Community, Identity, Stability: The Scientific Society and the Future of Religion in Aldous Huxley's Brave New World," English Studies in Canada 37.3-4 (2011), 85; and Evelyn Cobley, Modernism and the Culture of Efficiency (Toronto: University of Toronto Press, 2009), 282-312.

36. Aldous Huxley, "Science and Civilization," The Hidden Huxley, ed. David Bradshaw (London: Faber and Faber, 1994), 109-10. While the majority of Huxley's readers assume that Brave New World satirizes science and Fordism, since the mid-1990s a small group, basing its views on Huxley's essays, have shown that Huxley was very enthusiastic about using science to shape society at the time he wrote his novel. See David Bradshaw, "Huxley's Slump: Planning, Eugenics, and the 'Ultimate Need' of Stability," in The Art of Literary Biography, ed. John Batchelor (Oxford: Oxford University Press, 1995), 151-71; Robert S. Baker, "Review Article: Aldous Huxley: History and Science between the Wars," Clio 25.3 (1996): 293-300; and Joanne Woiak, "Designing a Brave New World: Eugenics, Politics, and Fiction," The Public Historian 29.3 (2007), 105-29. 
It is worth repeating that Huxley is not presenting here a nightmare vision of the future, but, as Huxley says, "an alternative to collapse." ${ }^{37}$ Granted, survival will come at a price, but survival is worth it: "It would certainly be worth forgoing a great deal of liberty for the sake of peace." 38 There are good reasons, in other words, for assuming that a world in which the "principal of mass production [is] at last applied to biology" (19) is not a world Huxley automatically or unproblematically rejected. Like Thomas More, Huxley crafted his fiction as a remedy for England's problems, in particular, the plight of the English manual labourer and the trauma of World War I. And again, like More, his venture into science fiction braids together utopian and dystopian elements. The novel tells us that Brave New World seems appalling until one considers both the alternatives and the problems that gave birth to the World State.

The conditions of England's working class deeply distressed Huxley. On the one hand, unemployment destroyed the soul. In an essay published in 1931, Huxley describes his horror at the "crowds of unemployed men who fill the streets of Middlesbrough (or for that matter of almost any other big northern town) with their slow, interminable procession. Dead men walking, walking from nowhere in particular to nowhere else, aimlessly and in silence." ${ }^{39}$ But the employed are not much better off. Manual labour, Huxley repeatedly says, kills the mind. To be sure, Huxley is no enemy of industrial progress. "A wellorganised factory is a work of art," he says, "a magnificent poem." ${ }^{0}$ The problem is that intellectual labour and its satisfactions belong to the "technicians and the organisers," the people Huxley calls the "artists of industry"; the workman, on the other hand, "is simply part of the material with which the artists work, one of the instruments he is compelled to use." 41 This kind of labour is "so dreary, so utterly boring," that Huxley feels "ashamed" in the presence of men condemned to this life, since he is "a man whose labours are not only thoroughly congenial to him, but also much more profitable than the, to his mind, odious

\section{Huxley, "Science and Civilization," 111.}

38. Huxley, "Science and Civilization," 111.

39. "Abroad in England," in The Hidden Huxley, 60 (originally published in Nash's Pall Mall Magazine, May 1931).

40. Aldous Huxley, "Sight-Seeing in Alien Englands," in The Hidden Huxley, 69 (originally published in Nash's Pall Mall Magazine, June 1931).

41. Huxley, "Sight-Seeing," 70. 
and intolerable business of his less fortunate fellows." ${ }^{2}$ The key term here is "mind," because for Huxley, the lack of intellectual stimulation-what he calls in another essay, the "psychological poverty" - is what makes factory work so repugnant. ${ }^{43}$

Echoing a passage in Henry Ford's My Life and Work dismissing such concerns because the average worker (according to Ford) "wants a job in which he does not have to think," Huxley recalls "the traditional consolation of the prosperous and the free. 'Believe me, my dear, they really don't feel as intensely as we do."44 (Not coincidentally, a "massive" copy of Ford's book, bound in "leather-surrogate," sits on a table in Mustapha Mond's office [196].) "Panygyrists" of the assembly line may claim that "low-level routine work [...] sets the mind free," but Huxley does not believe it for a second, and he concludes his essay, "Sight-Seeing in Alien Englands," wondering whether "the work which keeps the mind occupied is not better, humanly speaking, than the work which leaves it free." 45

In Brave New World, Huxley responded to the problem of intellectually enervating labour by summoning, as Huxley puts it in "Science and Civilization," "a lot of science, well applied." 46 The solution Huxley dreams up is to have everyone designed, both physically and psychologically, from gestation to birth, to be happy in the jobs they will occupy: "All conditioning aims at that: making people like their inescapable social destiny" (26). Since the world needs people who work in hot, adverse conditions that would make most people miserable (certainly they would make Huxley miserable), embryos destined for "the tropics to be miners and acetate silk spinners and steel workers" (26) are subjected to x-rays that inculcate "a horror of cold" (26). Similarly, the world needs chemicals, and so the next generation of "chemical workers were being trained in the toleration of lead, caustic soda, tar, chlorine" (26). The bottles of those destined to work on rockets in mid-air are "kept in constant rotation" so as to "improve their sense of balance" (27). The point is not to merely inure

\section{Huxley "Sight-Seeing," 71.}

43. Aldous Huxley, "The Victory of Art over Humanity," The Hidden Huxley, 78 (originally published in Nash's Pall Mall Magazine, July 1931).

44. Henry Ford, in collaboration with Samuel Crowther, My Life and Work (New York: Doubleday, 1923), 103; Huxley, "Sight-Seeing," 71. Huxley quotes a slightly different passage in "Sight-Seeing," 74-75.

45. Huxley, "Sight-Seeing," 75, 76.

46. Huxley, "Science and Civilization," 106. 
them to discomfort but "to associate topsy-turvydom with well-being: in fact, they're only truly happy when they're standing on their heads" (27).

In another essay, "The Victory of Art over Humanity," Huxley responded with revulsion at the sight of workers "lugging [sheep and oxen] corpses about in arctic cold and darkness," and the unspoken assumption is that these workers are equally repulsed by what they must do to earn a living. ${ }^{47}$ So Huxley imagines a future in which such workers are overjoyed by their occupations, as demonstrated by the Epsilon-Minus-Semi-Moron whose job working an elevator grants him ecstatic, even religious, happiness: ${ }^{48}$

\section{“Roof!"}

He flung open the gates. The warm glory of afternoon sunlight made him start and blink his eyes. "Oh, roof?" he repeated in a voice of rapture. He was as though suddenly and joyfully awakened from a dark annihilating stupor. "Roof!" (64)

It may very well be that the Epsilon, etc. elevator attendant feels what John (a.k.a. "the Savage") calls a "sort of false, lying happiness" (163), but given the description, that is not how the Epsilon, if he had the capacity to define his emotions, would view the matter. For him, operating the elevator is utopian bliss.

To be sure, there is something appalling to Huxley and, judging by the reviews, his first readers, about deliberately creating humans of subpar intelligence and predestinating them for particular occupations. Then as today, most of the novel's readers likely belong to the privileged few with the education and the leisure to spend time reading fictions. Admittedly, I am making an assumption here, but I think it is safe to say that, in the novel's terms, the book's readers are Alphas, and if made to do Epsilon-Semi-Moron work, such as operating an elevator, working in a mine, or lugging animal carcasses about, would, as Mustapha Mond tells John, "go mad, or start smashing things up" (200). But Huxley realizes that such work must be done. Elevators must be run, and the minerals used in this technological society must be dredged out of the earth. Our society requires dirty, unpleasant, mind-numbingly dull, 
and sometimes physically arduous work. These are, as Henry the helicopter pilot says, "indispensable services" (76). And so, Huxley invents a society in which the people who perform these jobs find them inexpressibly fulfilling, not "odious and intolerable." ${ }^{49}$ Unlike post-World War I Britain, in the World State, "Everybody's happy now" (77).

However, Huxley is concerned with much more than the psychological or emotional well-being of the World State's citizens. Over and over again, Huxley emphasizes that individual happiness is not a goal in itself, but a contributor to the World State's primary end: stability. "Bokanovsky's process," the Director tells his charges, "is one of the major instruments of social stability" (18); "the planetary motto" is "community, identity, stability" (18); "Stability', said the Controller, 'stability. No civilization without stability'" (47); even more to the point, the Controller declares stability "The primal and the ultimate need" (48). Why this obsession with stability, which even governs how the World State organizes time "in this year of stability, A. F. 632" (16)?

The answer is World War I. ${ }^{50}$ Huxley filled his letters to friends and family with the trivia of student life (he attended Balliol College, Oxford), yet they "are littered with the casualties of war," as Jake Poller nicely puts it. ${ }^{51}$ After reporting to his father on a trip to Scotland and including a rather dreamy French sonnet that he penned, Huxley noted that "poor Bob Gibson [Fellow and Tutor at Balliol] is killed," and in another letter, that a friend has "developed gas-gangrene." 52 The number of casualties is such that "one anticipates that none of one's friends will be left alive," and Huxley observed to a wounded colleague, "These maximal horrors of war are really too unthinkably appalling." 53

In Brave New World, Huxley transmutes World War I into the "Nine Years' War," the event that led directly to the creation of the World State. We do not find out much about the Nine Years' War, such as who started it and why. But after we learn that "the Nine Years' War began in A.F. 141" (32), Huxley gives us a

49. Huxley, "Sight-Seeing," 71.

50. While a number of critics have written on Huxley's views about technology, science, and labour (see note 35, above), the shaping presence of World War I in Brave New World is surprisingly neglected.

51. Jake Poller, “'These Maximal Horrors of War': Aldous Huxley, Garsington, and the Great War," Aldous Huxley Journal 6 (2006): 64.

52. Huxley, Letters, 73, 82. On Robert Gibson, see Balliol College War Memorial Book 1914-1919 (Glasgow: University Press, 1924), 179-80.

53. Huxley, Letters, 81, 84. 
list of chemical weapons, such as "phosgene [the gas responsible for most of the deaths from chemical warfare during World War I], chloropicrin [used in the manufacture of poison gas], ethyl iodoacetate [tear gas], diphenylcyanorsine [a vomiting agent used by the Germans] [...] not to mention hydrocyanic acid [which would later be the key ingredient in Zyklon B, the gas used in Nazi death camps]" (53). We also learn that "anthrax bombs" were dropped "in the Kurfurstendamm and the Eighth Arrondissement" (53), and we are left to imagine the inhabitants of these elegant neighborhoods dying horribly from this disease. The War involved more conventional means of mass death as well: "Eight hundred Simple Lifers were mowed down by machine guns" (55), but the emphasis is always on chemical warfare: "Then came the famous British Museum Massacre. Two thousand culture fans gassed with dichlorethyl sulphide [mustard gas]" (56). ${ }^{54}$ Huxley does not go into great detail about how the war ended, but it is clear the world somehow figured out that they were at a crossroads. Echoing the choice in "Science and Civilization" between a world controlled by science and total "collapse," 55 the world realized that either everything changes, or everybody dies: "There was a choice between World Control and destruction. Between stability and ..." (53). Huxley does not finish the sentence, but it is not hard to fill in the blank: economic collapse, chemical warfare, and massacres until there's no one left. So, the world decided to start over again with a clean slate: history, gone; the family, gone. (41, 44, 45, 47). Anything that stands between the individual and the fulfillment of desire is gone (50). Anything that results in "horrible emotions" is gone, because, to quote one of the World State's truisms, "When the individual feels, the community reels" (92), and when the community reels, people die. The dystopia of nonstop consumption and sex, of manufactured people predestined to particular positions, is really the utopia of a world without war, especially chemical war.

Mustapha Mond is painfully, precisely aware that there's a cost to stability, but it is one that he willingly (if not happily) pays: "You've got to choose

54. Donald Watt notes that in the first version of this passage, Huxley had the two thousand culture fans "squashed by tanks," which he then changed to gas; see "The Manuscript Revisions of Brave New World," in Critical Essays on Aldous Huxley, ed. Jerome Meckier (New York: G. K. Hall, 1996), 5. Huxley would later become a pacifist, but chemical weapons-which were outlawed in 1925-seem to have especially repelled him. He included an entry on "Chemical Warfare" in An Encyclopaedia of Pacifism, supposedly edited by Huxley but mainly written by him (1937; rpt. New York: Garland, 1972), 13-16. There is no entry for tanks. 55. Huxley, "Science and Civilization," 111. 
between happiness and what people used to call high art. We've sacrificed the high art" (199). Certainly, Huxley's readers, including I assume most today, recoil at trading Shakespeare for "the feelies," and religion for soma. We find ourselves reflexively agreeing with John when he says "Othello's good. Othello's better than those feelies" (199), especially since Mond concurs: “'Of course it is', the controller agreed. 'But that is the price we have to pay for stability"' (199).

However, consider this photograph by Dmitri Baltermants depicting the aftermath of a 1942 Nazi massacre of Jews in the Ukrainian city of Kerch:

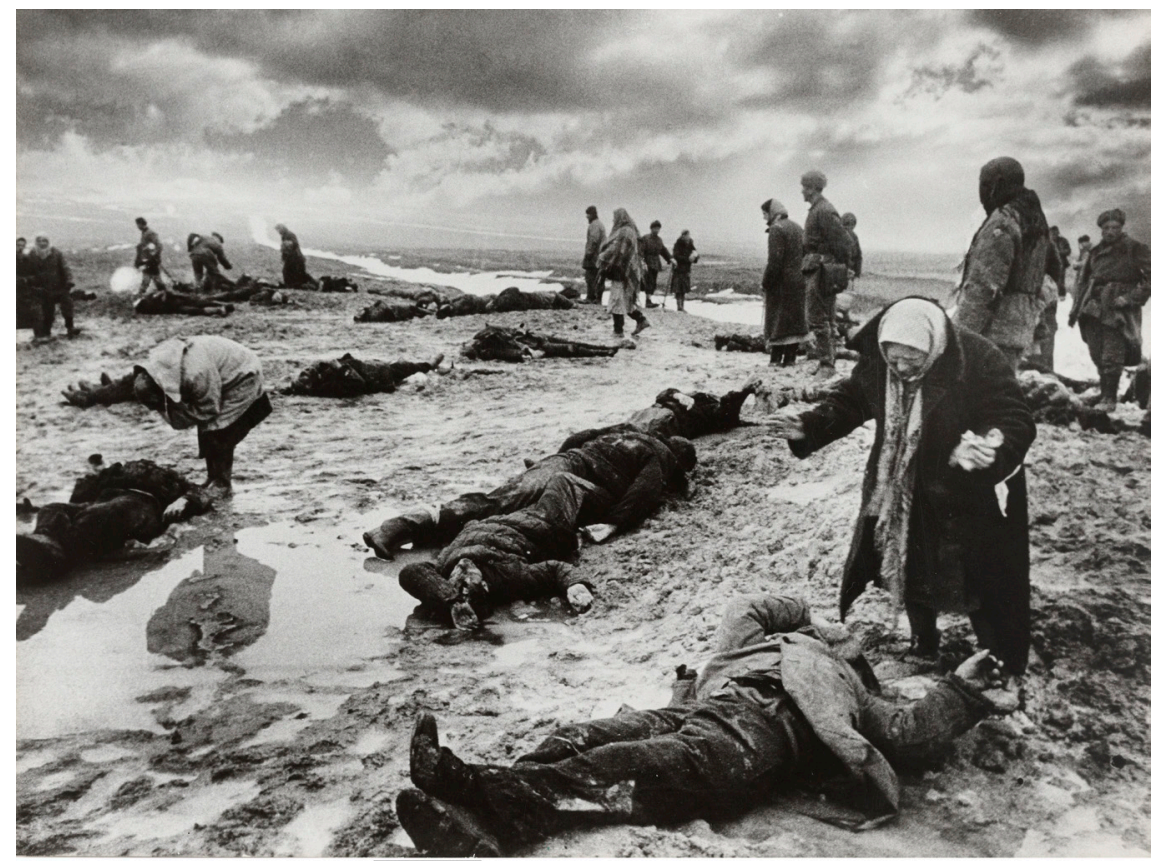

Figure 1. Baltermants, Dmitri (1912-1990). Grief. 1942.

Cornelius N. Bliss Memorial Fund. The Museum of Modern Art.

The question Huxley poses is not whether those educated at Oxford (as Huxley was) would find the trade worthwhile, but whether the women in the photograph who have just discovered the bodies of their husbands or sons dead in the mud would make the trade. Would Bob Gibson, or the friend who "developed gas-gangrene," if they were given the option, trade Shakespeare 
for the feelies to avoid what happened to them and so many others? ${ }^{56}$ As with More's fiction, determining whether Brave New World is a utopia or a dystopia depends on whom you ask.

\section{3.}

Which brings me to Dave Eggers's novel, The Circle. Like More and Huxley, Eggers based his novel on recent history, and again like More and Huxley, his utopia braids together the positive and the negative. ${ }^{57}$ The ground for Eggers's novel is the dream that the web will cure just about everything wrong with the world. Starting in the mid-1990s, the web, it was predicted, would "level social hierarchies, distribute and personalize work" and create "a single, harmonious electrosphere." ${ }^{58}$ No less a sage than Ronald Reagan predicted in 1989 that "the Goliath of totalitarian control will rapidly be brought down by the David of the microchip." ${ }^{59}$ And according to no less a sage than U2's lead singer, Bono, cell phones are the key to social change: "Because there's not just one big lever of power anymore; there's millions of levers, and you've got some in your hands. When we press 'em together [...] at the same time [...] that's when things really start happening." ${ }^{10}$ Others have argued for the centrality of the web and social media in the Arab Spring. ${ }^{61}$

56. Huxley, Letters, 73, 82.

57. As of this writing, critical writing on The Circle has only started to develop. See Regina Martin, "State and Corporate Dystopianism in Nineteen Eighty-Four and Dave Eggers's The Circle," in Nineteen Eighty-Four (Ipswich: Salem, 2016), 55-67, and John Masterson, "Floods, Fortresses, and Cabin Fever: Worlding 'Domeland' Security in Dave Eggers's Zeitoun and The Circle,' American Literary History 28.4 (2016): 721-39.

58. Fred Turner, "How Digital Technology Found Utopian Ideology: Lessons from the First Hackers' Conference," in Critical Cyber-Culture Studies, ed. David Silver and Adrienne Massanari (New York: New York University Press, 2006), 257.

59. “Reagan Urges 'Risk' on Gorbachev: Soviet Leader May Be Only Hope for Change, He Says," Los Angeles Times, 13 June 1989, http://articles.latimes.com/1989-06-13/news/ mn-2300_1_soviets-arms-control-iron-curtain.

60. Joe Jervis, "Bono Turns up the Volume for Social Enterprise," The Guardian, 14 November 2012, https:// www.theguardian.com/social-enterprise-network/2012/nov/14/social-enterpise-bono-georgetown.

61. Erika R. George, “Tweeting to Topple Tyranny, Social Media and Corporate Social Responsibility: A Reply to Anupam Chander," The Circuit 2.43 (2011): 24-25, http://scholarship.law.berkeley.edu/ clrcircuit/43. 
Obviously, the dreams of the Arab Spring did not pan out, but tech utopianism (and triumphalism) remains undiminished today, as evidenced by the rhetoric surrounding MOOCs. In his keynote address to the 2013 Microsoft Faculty Summit, Bill Gates put forward MOOCs as the panacea for all the problems besetting higher education (e.g., accessibility, rising tuition, debt, etc.). We are now, Gates declared, in a "'golden era' of learning, thanks to massive open online courses and easy access to information." 62 Thomas Friedman, Internet booster and New York Times columnist, is equally utopian in his hopes for MOOCs:

Nothing has more potential to unlock a billion more brains to solve the world's biggest problems. And nothing has more potential to enable us to reimagine higher education than the massive open online course, or MOOC, platforms that are being developed by the likes of Stanford and the Massachusetts Institute of Technology and companies like Coursera and Udacity. ${ }^{63}$

As the Borg in Star Trek says, resistance is futile; "There is a new world unfolding," opines MIT's president, L. Rafael Reif, "and everyone will have to adapt." 64

Eggers embodies these utopian visions in a tech company, the Circle, which combines Facebook, Google, and Apple. Three people run this business: Eamon Bailey, the visionary; Tom Stenton, the businessman; and Ty Gospodinov, the programming genius who started it all and who seems to have

62. Sara Grossman, "Bill Gates Discusses MOOCs at Microsoft Research's Faculty Summit," The Chronicle of Higher Education, 16 July 2013, http://www.chronicle.com/blogs/wiredcampus/ bill-gates-discusses-moocs-at-microsoft-researchs-faculty-summit/44809.

63. Thomas Friedman, "Revolution Hits the Universities," New York Times, 26 January 2013, http://www. nytimes.com/2013/01/27/opinion/sunday/friedman-revolution-hits-the-universities.html.

64. Quoted in Friedman, “Revolution.” Despite the admission by Udacity's founder, Sebastian Thrun, that they were peddling a "lousy product" (https://www.fastcompany.com/3021473/udacity-sebastianthrun-uphill-climb), enthusiasm for MOOCs by college and university administrators remains undiminished. See, for example, Joshua Kim, "Open Online Education and Liberal Arts Schools," Inside Higher Ed, 15 November 2016, https://www.insidehighered.com/blogs/technology-and-learning/ open-online-education-and-liberal-arts-schools. Even so, the era of unqualified tech utopianism may be coming to a close. See Victor Luckerson, "The End of Tech Optimism," The Ringer, 30 December 2016, https://theringer.com/end-of-tech-optimism-facebook-twitter-airbnb-uber-473a25df0d25\#.w0y4foclz. 
disappeared from the company (he is never seen on the campus anymore). Together, they have created a company that promises to transform the dystopia of everyday life, with its redundancies and inconveniences, its dangers and intractable political problems, into a utopia of web-based interconnectedness.

At first, nobody had any intention of changing the world. Ty wanted to make the web more user-friendly and convenient, so he invented the Unified Operating System, which combined "everything online that had heretofore been separate and sloppy. [...] Instead, he put all of it, all of every user's needs and tools, into one pot and invented TruYou-one account, one identity, one password, one payment system, per person" (20-21). Convenience, however, meant the end of anonymity:

You had to use your real name, and this was tied to your credit, your bank, and thus paying for anything was simple. One button for the rest of your life online. To use any of the Circle's tools [...] you had to do so as yourself, as your actual self, as your TruYou. The era of false identities, identity theft, multiple user names, complicated passwords and payment systems was over. (21)

So was the previously anarchic nature of the Internet itself: "Overnight, all comment boards became civil, all posters held accountable. The trolls, who had more or less overtaken the internet, were driven back into the darkness" (22). To invert the famous New Yorker cartoon from 5 July 1993, now, on the Internet, everybody knows you are a dog.

Of course, users were not the only group to find TruYou convenient: because the program made "everything tied together and trackable $[\ldots]$ those who wanted or needed to track the movements of consumers online had found their Valhalla" (21-22). But in this fiction, as in reality, nobody cares. Since users no longer have to "memorize twelve identities and passwords" or "tolerate the madness and rage of the anonymous hordes," they are thrilled with TruYou (22), never mind that everything they do online is tracked for marketing purposes.

However, the Circle's goal quickly goes beyond improving the usability of the web. The company intends "to create a safer and saner world" (446) through social media-a utopia, in other words. On More's island, "everybody is under the eyes of all" (Utopia, 147), and that is exactly what happens in this novel, 
thanks to the Circle's newest product: a small camera the size of a lollipop that broadcasts "high-def-quality" images through a satellite connection. After Mae "borrows" a kayak and gets caught, thanks to one of these cameras, she has a colloquy with Eamon Bailey in which he elevates "being under the eyes of all" to a grand, moral principle. Secrets (as More had noted) "are the enablers of antisocial, immoral and destructive behavior" (289). Therefore, if we all behaved as if we are watched all the time:

it would lead to a more moral way of life. Who would do something unethical or immoral? Or illegal if they were being watched? If their illegal money transfer was being tracked? If their blackmailing phone call was being recorded. [...] If their philandering was being documented in a dozen ways. (290)

"Being under the eyes of all" will do even more than eradicate crime or immoral behaviour; it will lead to human perfection: "We can solve any problem. We can cure any disease, end hunger, everything, because we won't be dragged down by all our weaknesses, our petty secrets, our hoarding of information and knowledge. We will finally realize our potential” (292).

But there is another side to this sunny, utopian vision, hinted at in this passage. Bailey starts by using himself as an example of how nonstop surveillance shapes conduct: when on a business trip, he would ask himself, "What would Karen think of this if she were watching ... ? This would gently guide my behavior, and it would prevent me from even approaching behavior she wouldn't like" (289). Then, Bailey makes a crucial admission, the import of which he seems entirely unaware: "we would finally be compelled to be our best selves. [...] In a world where bad choices are no longer an option, we have no choice but to be good" (290; emphasis in the original). Bailey takes his voluntary choice to imagine himself observed and renders observation involuntary. By eliminating choice, by being, as he says, compelled to act or not act in a particular way, the Circle closes the door on choice. Furthermore, lack of moral choice in the Circle's world leads, it seems, to lack of ideological choice. As Mae says, "if all the doors are open, physically and metaphorically, there's only one truth" (297), or as an over-enthusiastic fan puts it, "You're gonna get everyone in one place, you're gonna teach them all the same things. There can be one morality, one set of rules" (395). Ultimately, even a few Circlers realize, 
after Stenton proposes replacing all government functions with his company, that "all this could or would lead to totalitarianism" (393).

These fears are more than justified. Like the voracious shark dredged out of the bottom of the ocean that Eggers uses as a (painfully obvious) symbol for the Circle, this company is a "very hungry, very evil empire" (401). As in 1984, people who get in its way do not end well:

every time someone started shouting about the supposed monopoly of the Circle, or the Circle's unfair monetization of the personal data of its users, or some other paranoid and demonstrably false claim, soon enough it was revealed that the person was a criminal or deviant of the highest order. [...] Who but a fringe character would try to impede the unimpeachable improvement of the world? (240)

For example, when Senator Williamson tries to break up the Circle's monopoly, as the Justice Department "did with Standard Oil, AT\&T and every other demonstrated monopoly in our history [because] their dominance of the Circle stifles competition and is dangerous to our way of free-market capitalism" (173), suddenly "very creepy stuff" appears on her computer (206), leading to her arrest, and, as Ty tells Mae, “That's about the hundredth person Stenton's done that to" (483). The Circle, as the book's resident curmudgeon, Mercer, puts it, may say they want to make the world better, but they are in fact aiming at being "the world's first tyrannical monopoly" (401).

On the one hand, this sounds exactly like both Utopia and 1984; surveillance, like the observing spirits in More's Utopia, like newspeak in 1984, will render crime impossible. At a demonstration of technologies the Circle might want to acquire, Stenton even speculates about a degree of observation that would make 1984 an oasis of privacy. A woman named Belinda offers up a program called "SeeYou" which purports to eliminate racial profiling by combining criminal records with a lollipop camera, and so a policeman can scan "any crowd, and he immediately sees all the people with prior convictions" (419). Repeat offenders show up in either orange (a low-level criminal) or red (violent crimes) (418). Belinda says that after a period, the records would be "expunged," but Stenton responds: "I hate that notion. [...] It's the community's right to know who's committed crimes. It just makes sense" (419), and so there is no possibility of parole, of reform. In the same session, another applicant 
proposes to use "motion sensor technology in the home, especially high-risk homes, to record any behavior outside the norm" (424), and so, "you're able to quickly ensure behavioral norms in any context" (426). Left unsaid, of course, is who gets to define "behavioral norms." If in 1984 the Party's "Revolution will be complete when the language is perfect" (52), thus eliminating even the possibility of dissent because "there will be no words in which to express it" (52), the Circle's mission will be complete when surveillance is perfect, 100 percent of web searches go through the Circle, and they "control all searches, and have full access to all data about every person" (483). This is exactly the world Ty fears and tries to convince Mae she should block. Unfortunately, he fails, and the book ends with Mae standing before the bed of her friend, Annie, the woman who brought her to the Circle in the first place, and who has slipped into a coma thanks to the revelations about her parents' sordid past (how this happens medically is unclear). Mae wants access to Annie's thoughts, to the only place in 1984 that remains private, "the few cubic centimeters inside your skull" (27): "They needed to talk about Annie, the thoughts she was thinking. Why shouldn't they know them? The world deserved nothing less and would not wait" (491).

And yet, More's Utopia and Huxley's Brave New World shape The Circle as much as 1984, as the impulse behind the Circle's most problematic, even fascistic, projects is not power or profit but (according to Eamon Bailey, at least) social good, even social justice. As Mae says, for every commercial application, "there were three [...] proactive applications that used the power of the technology to improve humanity" (418). For example, the ChildTrack program: a tiny chip, not visible to the naked eye, gets implanted in a child's ankle bone, rendering this person completely trackable. It's not hard to see the privacy issues, especially since there doesn't seem to be a cut-off date by which the chip gets deactivated. But the motivation for this program is absolutely irreproachable. Francis, the program's inventor, abused as a child, wants to make sure that nothing of the sort ever happens again:

think about a world where there could never again be a significant crime against a child. None possible. The second a kid's not where he's supposed to be, a massive alert goes off, and the kid can be tracked down immediately. Everyone can track her. All authorities know instantly she's missing, but they know exactly where she is. They can call the mom 
and say, "Hey, she just went to the mall," or they can track down some molester in seconds. (89)

What parent has not dreamed of such a device? Similarly, by making voter registration an immediate result of setting up a TruYou account, and by requiring every voting-age citizen to have a Circle account, and then by requiring everyone eligible to vote, one would solve the problem of poor voter turnout (387-90). ${ }^{65}$ Again, the social good achieved seems to outweigh the loss of privacy.

Furthermore, society would be better protected from criminals, who could no longer could hide. In her demonstration of "the ultimate search tool ... SoulSearch" (445), Mae uses the power of the web and the "lollipop" cameras to track down Fiona Highbridge, a woman who murdered her children by locking them in a closet while she went to Spain on vacation. Highbridge escaped custody and has not been seen "for a decade." With SoulSearch, three billion Circle users across the globe all join together to find her, and in six minutes, a woman missing for ten years is found and brought to justice (450). Racism could also be eliminated. Belinda's criminal tracking program, SeeYou, may seem a perfect instrument for a police state, but the underlying motivation is to get rid of racial profiling:

These practices only create more animosity between people of color and the police. See this crowd? It's mostly young men of color, right? A police cruiser by an area like this, and they're all suspects, right? Every one of these men might be stopped, searched, disrespected. But it doesn't have to be that way. (418)

As with ChildTrack, who could object to any of these results?

Massive surveillance will also rid the world of tyranny via the small, inexpensive "lollipop" cameras. Certainly, this device allows you to check surf or traffic conditions, but the more important, utopian use of this technology will be to prevent human rights abuses (exactly as Ronald Reagan predicted). Switching to the cameras in Tahir Square, Egypt, Bailey says, "There would

65. See, example, Drew Desilver, "U.S. Voter Turnout Trails Most Developed Countries," Pew Research Center, 2 August 2016, http://www.pewresearch.org/fact-tank/2016/08/02/ u-s-voter-turnout-trails-most-developed-countries/. 
be instant accountability. Any soldier committing an act of violence would be instantly recorded for posterity. [... The cameras] will prevent abuses of power" (66). Bailey reveals that fifty cameras now cover Tianamen Square, and China is not the only authoritarian regime now under the eyes of all: "a dozen authoritarian regimes, from Khartoum to Pyongyang" (67) now have cameras in their midst. How can this be bad? Because it will lead to total control, but as in More's Utopia, and Huxley's Brave New World, the dystopia results from utopian solutions to real problems. And would the mother whose child has been kidnapped, the young person of colour regularly harassed by the police, the protestors in Tahir Square shot by the security forces, say that the price is too high? That is the question all three authors invite us to ask.

I want to end by looking briefly at how Eggers reverses the usual utopian/ dystopian dynamic. In both More and Huxley, utopia segues into dystopia, but Eggers moves in the opposite direction through his treatment of social media.

Every interaction Mae has in this book gets rated. As Mercer puts it (negatively): in the Circle's world, everyone lives "willingly, joyfully, under constant surveillance, watching each other always, commenting on each other, voting and liking and disliking each other, smiling and frowning" (367). ${ }^{66} \mathrm{Mae}$ happily dives into what seems a dystopia of nonstop and ever-proliferating surveys, tweets, and social media connections. Why? Because they allow Mae to feel that she matters. After a "zing" (the Circle's version of a tweet) she wrote "was forwarded 322 times [...] the validation felt good" (54). After Mercer delivers a stinging indictment of the Circle's social media-centric culture, comparing it to the "wasted," "hollow," and "diminished" feeling you get after binging on junk food, Mae responds, "I never feel diminished" (134). In fact, she found signing a bunch of petitions "energizing" (134). True, Eggers carefully implies the limits of using social media to effect change. A "fundraiser" for a school in Pakistan "was able to amass 2.3 million smiles for the school" (332), but not, it seems, any actual money. Even worse, Mae says that Circlers have sent "over 180 million frowns" (345) to the Chinese government protesting their treatment of an artist whose sculpture the Circle has installed, but on the next page, we learn that "Efforts to contact the artist [...] had been unsuccessful" (346). One could also say that Mae is deluded, a perfect example of false consciousness, tricked by the Circle's propaganda into mistaking what John in Brave New World calls a "sort 
of false, lying happiness" (163) for something genuine. Except that at the book's end, she says something that is so tragic, so deeply human, it is impossible to dismiss. When Ty asks, "who wants to be watched all the time?" Mae responds:

I do. I want to be seen. I want proof I existed. [...] Most people do. Most people would trade everything they know, everyone they know-they'd trade it all to know they've been seen, and acknowledged, that they might even be remembered. We all know the world is too big for us to be significant. So all we have is the hope of being seen, or heard, even for a moment. (485)

From the dystopia of non-stop rating, tweeting, and surveillance comes the utopia of knowing one's existence made a difference. It's very hard to argue with that. 